\begin{tabular}{|c|c|c|}
\hline & Int.J.Curr.Microbiol.App.Sci (2016) 5(11): $45-50$ & \multirow{4}{*}{ 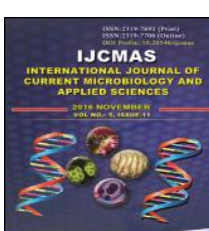 } \\
\hline & International Journal of Current Microbiology and Applied Sciences & \\
\hline & ISSN: 2319-7706 Volume 5 Number 11 (2016) pp. $45-50$ & \\
\hline EXCELLENT & http://www.ijcmas.com & \\
\hline PUBLISHERS & & www:ijemas,com \\
\hline
\end{tabular}

Original Research Article

http://dx.doi.org/10.20546/ijcmas.2016.511.005

\title{
A Descriptive Study to Assess the Bio-Psychosocial Consequences of Late Marriages among Late Married Couples Residing in Selected Areas of District Mohali, Punjab, India
}

\author{
Manjot $^{1 *}$ and V.Santhalakshmi ${ }^{2}$ \\ Mata Sahib Kaur College of Nursing, Mohali, India \\ *Corresponding author
}

Keywords

Late married couple, Biological ConsequencesPsyc hological Consequences and Sociological Consequences.

\begin{tabular}{l}
\hline Article Info \\
\hline Accepted: \\
04 October 2016 \\
Available Online: \\
10 November 2016
\end{tabular}

\begin{abstract}
A B S T R A C T
Marriage is an ancient practice, although its meaning may have changed throughout time and space. Due to paradigm shift in society, individuals are becoming more goal oriented, So this put institution of marriage at back-foot. The aim of the study is to assess the bio-psychosocial consequences of late marriage among late married couples residing in selected areas of district Mohali, Punjab. A quantitative approach with descriptive research design was adopted. By Purposive sampling technique 150 late married couples were selected. Data was collected by semistructured interview schedule for biological consequences, rating scale for psychological consequences and sociological consequences were used in the study. Analysis of data was done using descriptive and inferential statistics. Study findings shows that late married couples i.e. $40.7 \%$ of couples had physical problem before and $41.3 \%$ after marriage, $20.7 \%$ of couples had problem in conception out of them majority $39.3 \%$ had endometritis, About $63.7 \%$ had problem during pregnancy, out of them majority $41.9 \%$ had anemia, $80.7 \%$ late married couple underwent caesarean section. $48.1 \%$ late married couple had post-partum problem, $48.8 \%$ newborn had problem at the time of birth, $89.3 \%$ of late married couples had positive psychological consequences and $82.7 \%$ had positive sociological consequences. It shows that late marriage had effect on biological consequences and more biological problems are found where as late marriage had positive effect on psychological and sociological aspect.
\end{abstract}

\section{Introduction}

Marriage is an ancient practice, although its meaning may have changed throughout time and space. The word 'marriage' means only a legal union between one man and one woman as husband and wife, and the word 'spouse' refers only to a person of the opposite sex who is a husband or wife.
Historically, in all the cultures/civilizations of the world, marriages were solemnized at quite a young age, and that age was nearly related to the age of puberty. In India too child marriage was the norm and it had the backing of religion also. The Vedas, purans etc. gave us insight about such religious 
sanctions. But with the advent of renaissance, modernity and industrial revolution in Europe, the concept of marriage has changed significantly. Then globalization has contributed in spreading such social changes in the whole world. India too couldn't resist them and over a couple of decades the average age of marriage has increased considerably. However, the marriage age has undergone a gradual but steady increase.

The trends indicate that more women opt for late marriage, it leads to late pregnancy. Marriage considered being a usual process in the life of human beings. In India, marriage is an important marker of the beginning of reproductive phase of life. Although reproduction is feasible and does take place to some extend outside of marriage, marital fertility is the major contributor to the fertility.

Every person wishes to make his or her marital life successful. History tells us that marriage was always and everywhere be under discussion. Every religion, every philosopher and practical wisdom has its own point of view. There is no doubt that every type of marriage has some particular factors which affect it such as personal maturity, level of understanding, independence of thoughts, intelligence, education, awareness, health, financial responsibilities, skills to manage family life, stress, strain, affects, lack of patience, religion and individual interests. As marriages are necessary for humans, marital adjustment and life satisfaction is equally important.

This study help to know the marital adjustment, life satisfaction and the biopycho-social consequences of the marriage among late married couples. Marital adjustment and life satisfaction has long been the focus of investigation and research in the west and western countries. However in Punjab this topic is not extensively studied.

The main objectives of this study include, to assess the bio-psychosocial consequences of late marriages among late married couples. And also to associate the bio-psychosocial consequences of late marriages with the selected socio- demographic variables.

\section{Materials and Methods}

In present study, quantitative research and descriptive research design approach was used under study. The study was conducted in selected areas of district Mohali(kharar and sohana). The target population of study consisted of late married couples residing in selected areas of district Mohali, Punjab. The sample consists of 150 late married couples. Non-probability purposive sampling technique and Semi-structured interview schedule for biological consequences, rating scale for psychological consequences and sociological consequences were used in the study. A study was conducted in the month of March 2016 Formal written permission was obtained from the Municipal Corporation of kharar and sohana after discussing the purpose and objectives of the study. Analysis and interpretation of data was done according to objectives of the study by using descriptive and inferential statistics.

\section{Results and Discussion}

\section{Demographical variable}

According to the age of husband, majority of husbands $57.3 \%$ belong to the age group of $32-35$ years, followed by $26.7 \%$ who belong to the age group $28-31$ years, $12.7 \%$ belong to the age group 36-39years and very least $3.3 \%$ belong to the age group of $\geq 40$. Majority of wives $55.3 \%$ belong to the 
age group of 32-35 years, followed by $30.0 \%$ belong to the age group $28-31,14.0 \%$ belong to the age group 36-39 years and very least $0.7 \%$ belong to the age group of $\geq 40$. Majority of husbands $61.3 \%$ belong to the age group 30-31 years, followed by $20.0 \%$ belong to the age group 28-29 years and very least $18.7 \%$ belongs to the age group of $\geq 31$.

According to the age at marriage of wife, majority of wives $54.7 \%$ belong to the age group 28-29 years, followed by $34.7 \%$ belong to the age group 30-31and very least $10.7 \%$ belong to the age group of $\geq 31$. With regard to duration of marriage, majority of couples $71.3 \%$ belong to the 1-3 years, followed by $15.3 \%$ belong to the $\geq 4$ years and very least $13.3 \%$ belong to the $<1$ years. Majority of husbands $75.3 \%$ were Graduate, followed by $18.0 \%$ were post graduate or more, $6.0 \%$ were studied till higher secondary, $0.7 \%$ were studied till secondary and none of them were $0 \%$ belong to no formal education and primary education. Majority of wives $62.7 \%$ were Graduate, followed by $20.0 \%$ were studied post graduate or more, $14.0 \%$ were completed higher secondary ,3.3\% were completed secondary and none of them were $0 \%$ belongs to no formal education and primary education. Majority of husbands $42 \%$ had Government job, followed by $35.3 \%$ had private job, $21.3 \%$ were self-employed and very few $1.3 \%$ wereUnemployed.Majority of wives $57.3 \%$ had Private job, followed by $22.7 \%$ were unemployed, $15.3 \%$ had government job and very least $4.7 \%$ were Self-employed. Majority of couples $78.7 \%$ had monthly family income $\geq 30001$, followed by $14.7 \%$ had income between 20001-30000, 5.3\% had income between $10001-20000$ and very few $1.3 \%$ had monthly family income $\leq 10000$. Majority of couples $56.7 \%$ belong to the Sikh religion, $26.7 \%$ belong to the Hindu religion, $9.3 \%$ were Christian and very few $7.3 \%$ were Muslim. Majority of couples 84\% had Arranged marriage and very few $16 \%$ had love marriage. Majority of couples $70.7 \%$ had Nuclear family and $29.3 \%$ had joint family.

Table1.1.shows frequency and percentage distribution of late married couples according to their biological consequences.

It depicts that $40.7 \%$ of late married couples had physical problem before marriage, out of them majority of the men $29.5 \%$ had hypertension , $23.0 \%$ females had PCOD, $18.0 \%$ females had hypertension , $16.4 \%$ had males had DM, $11.5 \%$ female had amemia and very least $1.6 \%$ females had DM. About $41.3 \%$ of late married couples had physical problem after marriage, out of them majority $40.3 \%$ of females had hypertension \& $37.1 \%$ males had hypertension, $16.1 \%$ had PCOD and very least $6.5 \%$ males had DM. About $90 \%$ of late married couples had conceived and $10 \%$ had not yet planned for conception.

Table 1.2:shows frequency and percentage distribution of late married couples according to their biological consequences.

It depicts that $20.7 \%$ of late married couples had problem in conception, out of them majority $39.3 \%$ had endometritis, $35.7 \%$ had low sperm count, $21.4 \%$ had abortion and very least $3.6 \%$ had PCOD. About $63.7 \%$ had problems during pregnancy, among them majority $41.9 \%$ had anemia during pregnancy, $31.4 \%$ had oligohydramnios, $11.6 \%$ had polyhydroamnios, $9.3 \%$ had gestational diabetes and very least $5.8 \%$ had hypertension. $22.2 \%$ of late married couples had intra partum complication out of them majority $66.7 \%$ had intra partum haemorrhage and $33.3 \%$ had retained placenta. Most of the $80.7 \%$ late married 
couples under went caesarean section and $19.3 \%$ had normal vaginal delivery.48.1\% late married couple had post-partum problems, out of them $58.5 \%$ developed post-partum haemorrhage and $41.5 \%$ had puerperal sepsis. About $48.8 \%$ problem in newborn at the time of birth, out of them $63.6 \%$ had low birth weight and $36.4 \%$ had respiratory distress.

Table. 2 depicts maximum number $(89.3 \%)$ of late married couples had positive psychological consequences and least $(10.7 \%)$ late married couples had negative psychological consequences.

Table.3 depicts most $(82.7 \%)$ of the late married couples had positive Sociological consequences and least (17.3\%) late married couples had negative Sociological consequences.

Table.1.1 Frequency and Percentage distribution of late married couples according to their biological consequences $(\mathrm{N}=150)$

\begin{tabular}{|c|l|c|c|}
\hline S. No. & Biological Consequences & Frequency (f) & Percentage (\%) \\
\hline 1. & Physical problem before marriage & $\mathbf{6 1}$ & $\mathbf{4 0 . 7}$ \\
\hline a. & Hypertension in males & $\mathbf{1 8}$ & $\mathbf{2 9 . 5}$ \\
\hline b. & Hypertension in females & 11 & 18.0 \\
\hline c. & DM in Males & 10 & 16.4 \\
\hline d. & DM in Females & $\mathbf{0 1}$ & $\mathbf{1 . 6}$ \\
\hline e. & PCOD & 14 & 23.0 \\
\hline f. & Anemia in Females & 07 & 11.5 \\
\hline 2. & Physical problem after marriage & $\mathbf{6 2}$ & $\mathbf{4 1 . 3}$ \\
\hline a. & Hypertension in Males & 23 & 37.1 \\
\hline b. & Hypertension in Females & $\mathbf{2 5}$ & $\mathbf{4 0 . 3}$ \\
\hline c. & DM in Males & $\mathbf{0 4}$ & $\mathbf{6 . 5}$ \\
\hline d. & PCOD & 10 & 16.1 \\
\hline 3. & Conception & 135 & 90 \\
\hline a. & Conceived & 15 & 10 \\
\hline b. & Not yet planed & \multicolumn{2}{|l}{} \\
\hline
\end{tabular}

Table.1.2 Frequency and percentage distribution of late married couples according to their biological consequences $(\mathrm{N}=135)$

\begin{tabular}{|c|l|c|c|}
\hline S. No. & Biological Consequences & Frequency (f) & Percentage (\%) \\
\hline $\mathbf{3 . 1}$ & Problem in conception & $\mathbf{2 8}$ & $\mathbf{2 0 . 7}$ \\
\hline a. & Endometritis & $\mathbf{1 1}$ & $\mathbf{3 9 . 3}$ \\
\hline b. & Low sperm count & 10 & 35.7 \\
\hline c. & Abortion & 06 & 21.4 \\
\hline d. & PCOD & 01 & 3.6 \\
\hline $\mathbf{3 . 2}$ & Problem during pregnancy & $\mathbf{8 6}$ & $\mathbf{6 3 . 7}$ \\
\hline a. & Anemia & $\mathbf{3 6}$ & $\mathbf{4 1 . 9}$ \\
\hline b. & Oligohydramnios & 27 & 31.4 \\
\hline c. & Polyhydroamnios & 10 & 11.6 \\
\hline
\end{tabular}




\begin{tabular}{|c|l|c|c|}
\hline d. & Hypertension & 05 & 5.8 \\
\hline e. & Gestational diabetes & 08 & 9.3 \\
\hline $\mathbf{3 . 3}$ & Intra partum complications & $\mathbf{3 0}$ & $\mathbf{2 2 . 2}$ \\
\hline a. & IPH & $\mathbf{2 0}$ & $\mathbf{6 6 . 7}$ \\
\hline b. & Retained placenta & 10 & 33.3 \\
\hline $\mathbf{3 . 4}$ & Type of delivery & $\mathbf{1 0 9}$ & $\mathbf{8 0 . 7}$ \\
\hline a. & Caesarean section & 26 & 19.3 \\
\hline b. & NVD & $\mathbf{6 5}$ & $\mathbf{4 8 . 1}$ \\
\hline $\mathbf{3 . 5}$ & Post-partum problems & $\mathbf{3 8}$ & $\mathbf{5 8 . 5}$ \\
\hline a. & PPH & 27 & 41.5 \\
\hline b. & Puerperal sepsis & 66 & 48.8 \\
\hline $\mathbf{3 . 6}$ & Problem in Newborn at the time & & 36.4 \\
\hline a. & Re birth & 24 & 63.6 \\
\hline b. & Low birth weight & 42 & \\
\hline
\end{tabular}

Table.2 Frequency and percentage distribution of late married couples according to their psychological consequences $(\mathrm{N}=150)$

\begin{tabular}{|c|l|c|c|}
\hline S. No. & Psychological Consequences & Frequency (f) & Percentage (\%) \\
\hline 1. & Positive (23-36) & 134 & 89.3 \\
\hline 2. & Negative (9-22) & 16 & 10.7 \\
\hline
\end{tabular}

Table.3 Frequency and percentage distribution of late married couples according to their sociological consequences $(\mathrm{N}=150)$

\begin{tabular}{|c|l|l|c|}
\hline S. No. & Sociological Consequences & Frequency (f) & Percentage (\%) \\
\hline 1. & Positive (21-32) & 124 & 82.7 \\
\hline 2. & Negative (8-20) & 26 & 17.3 \\
\hline
\end{tabular}

Findings related to association of the biopsychosocial consequences of late marriages with the selected sociodemographic variables

- In study findings, there was statistically significant association between age at marriage of husband and Physical problem before marriage

- There was statistically significant association between type of marriage and Physical problem after marriage
- There was statistically significant association between age of husband, age of wife and type of delivery

- There was statistically significant association between duration of marriage and Post-partum problem

- There was statistically significant association duration of marriage and newborn had problem at the time of birth

- There was statistically significant association between age of wife, monthly 
family income and Psychological Consequences

- There was statistically significant association between age of wife, age at marriage of wife, duration of marriage, education of wife, occupation of husband, occupation of wife, monthly family income, type of family and Sociological Consequences

The conclusion drawn from the present study was the late marriage had effect on biological Consequences and more biological problems are found in late married couples such as $63.7 \%$ had problem during pregnancy and $80.7 \%$ late married couple underwent caesarean section where as late marriage had positive effect on psychological consequences and sociological consequences.

\section{References}

Arshad, M., Mohsin, N., Mahmood, K. 2014. Marital adjustment and life satisfaction among early and late marriages. J. Education and Practice, 5(17): 83-90.

Cherlin, A. 2009. Marriage, divorce, remarriage. Harvard University Press.

Francis, C. 2004. Early marriage and pregnancy. Nursing J. India, 95(9): 201.

Loke, A.Y., Poon, C.F. 2011. The health concerns and behaviours of primigravida: comparing advanced age pregnant women with their younger counterparts. J. Clin. Nursing, 20(7-8): 1141-50.

Marriage S.O. African J. Social Sci., 2(3): $135-44$

\section{How to cite this article:}

Manjot and V. Santhalakshmi. 2016. A Descriptive Study to Assess the Bio-Psychosocial Consequences of Late Marriages among Late Married Couples Residing in Selected Areas of District Mohali, Punjab. Int.J.Curr.Microbiol.App.Sci. 5(11): 45-50. doi: http://dx.doi.org/10.20546/ijcmas.2016.511.005 